\title{
Photosynthetic light requirements and vertical distribution of macroalgae in newly ice-free areas in Potter Cove, South Shetland Islands, Antarctica
}

\author{
D. Deregibus ${ }^{1}$ - M. L. Quartino ${ }^{1,2}$ - G. L. Campana ${ }^{1,3}$ F. R. Momo ${ }^{4,3}$ • \\ C. Wiencke ${ }^{5}$ K. Zacher ${ }^{5}$
}

Received: 30 October 2014/Revised: 27 December 2014/Accepted: 9 March 2015/Published online: 21 March 2015

(C) Springer-Verlag Berlin Heidelberg 2015

\begin{abstract}
In Potter Cove, Antarctica, newly ice-free areas appeared due to glacial retreat. Simultaneously, the inflow of sediment increased, reducing underwater photosynthetically active radiation (PAR, 400-700 nm). The aim of this study was to determine the photosynthetic characteristics of two macroalgal species colonizing three newly icefree areas, A1, A2 and A3, with increasing degree of glacial influence from A1 to A3. Turbidity, salinity and temperature were measured, and light attenuation coefficients $\left(K_{\mathrm{d}}\right)$ calculated and considered as a proxy for glacial sediment input. The lower depth distribution of the red alga Palmaria decipiens and the brown alga Himantothallus grandifolius was $10 \mathrm{~m}$ in A3, $20 \mathrm{~m}$ in A2 and $30 \mathrm{~m}$ in A1. Both species were then collected, at 5 and $10 \mathrm{~m}$ at all areas. Photosynthetic parameters and the daily metabolic carbon
\end{abstract}

This article is an invited contribution on Life in Antarctica: Boundaries and Gradients in a Changing Environment as the main theme of the XIth SCAR Biology Symposium. J.-M. Gili and R. Zapata Guardiola (Guest Editors).

D. Deregibus

dderegibus@dna.gov.ar

1 Departamento de Biología Costera, Instituto Antártico Argentino, Cerrito 1248, 1010AAZ Buenos Aires, Argentina

2 Museo Argentino de Ciencias Naturales "B. Rivadavia”, Av. A. Gallardo 470, C1405DJR Buenos Aires, Argentina

3 Departamento de Ciencias Básicas, Universidad Nacional de Luján, Ruta 5 y Avenida Constitución, 6700 Luján, Buenos Aires, Argentina

4 Instituto de Ciencias, Universidad Nacional de General Sarmiento, J.M. Gutiérrez 1150, B1613GSX Los Polvorines, Argentina

5 Alfred Wegener Institute, Helmholtz Centre for Polar and Marine Research, Am Handelshafen 12, 27570 Bremerhaven, Germany balance $(\mathrm{CB})$ were determined. $K_{\mathrm{d}}$ was significantly higher in $\mathrm{A} 3$ compared with $\mathrm{A} 1$ and $\mathrm{A} 2$. The $\mathrm{CB}$ of $P$. decipiens was significantly higher in A1 followed by $\mathrm{A} 2$ and $\mathrm{A} 3$, and significantly higher at shallower than at greater depth. For H. grandifolius $\mathrm{CB}$ was significantly lower in $\mathrm{A} 3$ and in $\mathrm{A} 2$ at deeper depths compared with the rest of areas and depths. The lower distribution limit of the algae was positively correlated to the light penetration. An increase in the sediment run-off due to global warming might lead to an elevation of the lower depth distribution limit but retreating glaciers can open new space for macroalgal colonization. These changes will probably affect macroalgal primary productivity in Potter Cove with consequences for the coastal ecosystem.

Keywords Depth zonation - Glacial retreat - Global warming $\cdot$ Seaweeds $\cdot$ Sediment inflow

\section{Introduction}

Over the last 50 years the Western Antarctic Peninsula (WAP) experienced rapid increases in temperature, especially during winter times, fast glacial retreat, and strong sea ice decreases (Turner et al. 2009; Ducklow et al. 2013). Glacial changes-melting and retreat-are affecting the coastal ecosystems in the WAP with conspicuous changes in pelagic and benthic communities (Barnes and Peck 2008; Schofield et al. 2010; Torre et al. 2012; Ducklow et al. 2013). In Potter Cove (25 de Mayo/King George Island) glacier melting and the retreat of the Fourcade Glacier has created newly ice-free areas (Rückamp et al. 2011) available for benthic colonization (Quartino et al. 2013). At the same time these areas are exposed to high loads of sediment input from subglacial waters (Eraso and 
Domínguez 2007). This is particularly relevant for macroalgal communities because an increase in sediment run-off into the water column reduces the light penetration constituting a constraint for photosynthesis (Schloss et al. 2012; Wiencke and Amsler 2012; Quartino et al. 2013).

The quantity and quality of light for photosynthesis and growth are decisive factors limiting macroalgal depth distribution (Lüning 1990). Antarctic macroalgae are shade adapted and tolerant to long periods of darkness due to the presence of ice cover and short day lengths during winter (reviewed in Zacher et al. 2009). Shade adaptation is reflected in a high photosynthetic efficiency $(\alpha)$ and low saturation points for photosynthesis $\left(I_{\mathrm{k}}\right)$ (Gómez et al. 2009). Antarctic seaweeds are-on the other hand-exposed to high levels of PAR and high UVR (ultraviolet radiation, 280-400 $\mathrm{nm}$ ) in spring after the sea ice break up (Wiencke and Amsler 2012). However, these high irradiances may be reduced in Potter Cove due to an increase in turbidity over the last decades during the warmer months (Campana et al. 2009; Zacher et al. 2009) and especially in summer (Schloss et al. 2012).

The lower depth distribution limit of macroalgae depends on their capacity to maintain a positive carbon balance to build up biomass as shown in Antarctic seaweeds for the first time by Gómez et al. (1997). During austral spring at noon, light can penetrate into the water column as deep as $30 \mathrm{~m}$ (1\% depth) at non-turbid sites in Potter Cove permitting a high transmittance of light and explaining the observed vertical distribution patterns of macroalgae (Gómez et al. 1997). A positive carbon balance, however, is evident during the ice-free periods only, compensating the low-light conditions in winter (Drew and Hastings 1992; Runcie and Riddle 2006; Zacher et al. 2009; Wiencke and Amsler 2012). Therefore, photosynthesis and also biomass formation is markedly seasonal in the Antarctic region (Miller and Pearse 1991; Wiencke et al. 2011).

In addition, other studies indicate that the daily exposure time is more important than the intensity of light for macroalgal productivity in coastal areas (Dennison and Alberte 1985; Matta and Chapman 1991; Gómez et al. 1997). Consequently, changes in light availability due to climate change could lead to changes in the vertical distribution limits and in benthic primary productivity (Gómez et al. 1997). Direct associations between increases in turbidity and decreases in macroalgal productivity have already been reported (Airoldi 2003; Anthony et al. 2004; Spurkland and Iken 2011; Pritchard et al. 2013).

Mathematical models relating light irradiance to photosynthesis are usually used to estimate primary productivity (Jassby and Platt 1976; Nelson and Siegrist 1987; Henley 1993, Jones et al. 2014). However, the values of the obtained photosynthetic parameters may differ depending on the selected fitting model (Smith 1936; Steele 1962; Webb et al. 1974; Jassby and Platt 1976; Cullen 1990; Frenette et al. 1993; Henley 1993). Frequently, values are not comparable between models and may lead to erroneous conclusions (Frenette et al. 1993). It is important to determine photosynthetic parameters obtained using the curve best fitting the experimental data. $P-I$ curves should include a minimum number of parameters with significant biological or physical meaning and be precise for a better approximation of the productivity in marine ecosystems (Jassby and Platt 1976; Nelson and Siegrist 1987). Since 1997 newly ice-free areas have been detected at the northeast shore of Potter Cove due to the retreat of the Fourcade Glacier (Rückamp et al. 2011; Quartino et al. 2013). Ecophysiological characteristics and responses of polar macroalgae in newly ice-free areas have been poorly studied (Becker et al. 2010). Knowledge of the minimum light requirements for macroalgae and of appropriate mathematical models relating light to physiological responses are needed to better understand and predict macroalgal survival, distribution and depth zonation in areas affected by glacial melting due to climate change.

This study aims to assess (1) the effects of depth and area (three newly ice-free areas) on the physiological responses and daily metabolic carbon balance of two important macroalgae and (2) the potential acclimation of macroalgae and perspectives of colonization in newly icefree areas with different light availability as a consequence of climate change. In addition, it is an initial effort to better estimate the primary productivity from our data, comparing two commonly used $P-I$ models (Webb et al. 1974; Jassby and Platt 1976). We hypothesize that algae growing in areas with lower light penetration (as a result of more intense glacial run-off) and at deeper depths acclimate their photosynthetic performance to these conditions. Thus, the physiological responses measured in this study would be phenotypic responses related to their habitat and light history.

\section{Materials and methods}

\section{Study site}

The study was conducted at Potter Cove $\left(62^{\circ} 14^{\prime} \mathrm{S}\right.$, $58^{\circ} 38^{\prime} \mathrm{W}$, Isla 25 de Mayo/King George Island, South Shetland Islands, Antarctica). At the north and east side of the cove, hard-bottom and bigger rocks are available for macroalgal colonization, whereas the inner side of the cove and the southern shore consist of soft-bottom habitats almost devoid of macroalgae (Klöser et al. 1996). Three different areas at the northeast side of the cove (Area 1, 2 and 3, A1, A2 and A3, respectively), which have been ice- 
free for different time spans (Rückamp et al. 2011) and which are characterized by different optical properties of the water column, were chosen as sampling sites (Quartino et al. 2013) (Fig. 1). A1 (S62 ${ }^{\circ} 3^{\prime} 39.3^{\prime \prime}$; W 58 $\left.48^{\circ} 46.4^{\prime \prime}\right)$ is an newly ice-free area with an approximate age of 25 years (ice free since 1990), A2 (S 62 $13^{\prime} 43.3^{\prime \prime}$; W $\left.58^{\circ} 40^{\prime} 07.8^{\prime \prime}\right)$ is closer to the inner part of the cove and appeared 17 years ago (ice free since 1997) and A3 (S 62 $13^{\prime} 25.9^{\prime \prime}$; W $\left.58^{\circ} 38^{\prime} 38.2^{\prime \prime}\right)$ is a rocky island at the inner end of the cove approximately 10 years old (ice free since 2003) (Fig. 1).

\section{Quantum irradiance measurements}

Underwater photosynthetically active radiation (PAR, 400-700 nm) was measured in two ways in the three areas:

Instantaneous PAR data $\left(\mu \mathrm{mol} \mathrm{m} \mathrm{m}^{-2} \mathrm{~s}^{-1}\right)$ were measured at $0,5,10,20$ and $30 \mathrm{~m}$ depth in each area, and were considered as a proxy for glacial sediment input. Measurements were performed weekly during the Austral Summer from December 2009 to March 2010, around noon, using a LI-COR datalogger (LI 1400, LI-COR, Lincoln, USA) equipped with a LI-COR 192 PAR underwater sensor (LI-COR, Lincoln, USA). Light attenuation coefficients $\left(K_{\mathrm{d}}\right)$ were calculated at two different depths points, between 0 and $30 \mathrm{~m}$ depth and between 0 and $10 \mathrm{~m}$ depth, according to Kirk (1994) as:

$K_{\mathrm{d}}=1 / z \times \ln \left(E_{0} / E_{\mathrm{z}}\right)$

where $E_{0}$ is the surface incident irradiance at $0 \mathrm{~m}$ (just below the water surface) and $E_{\mathrm{z}}$ is the irradiance at 30 or $10 \mathrm{~m}$ depth. Low $K_{\mathrm{d}}$ values describe transparent water with little attenuation of radiation, whereas high $K_{\mathrm{d}}$ values occur due to the presence of high quantities of suspended particles in the water column.
Additionally, continuous PAR measurements were taken every 15 min over seven consecutive days in summer 2009-2010 at 0, 5, 10, 20 and $30 \mathrm{~m}$ depth in each area. Measurements were performed using an Odyssey Photosynthetic Irradiance Recording System (Data Flow Systems, Christchurch, New Zealand). Light meters were calibrated 5 days prior to deployment against a LI-COR LI 1400 datalogger equipped with a LI-COR 190 PAR sensor. The LI-COR and Odyssey light loggers were installed during sunlight hours and measured simultaneously every 5 min during $4 \mathrm{~h}$. Each Odyssey logger measurement was then correlated against the LI-COR measurement by linear regression and the individual slope (correlation factor) used to transform the counts of the Odyssey logger into $\mu \mathrm{mol} \mathrm{m} \mathrm{m}^{-2} \mathrm{~s}^{-1}$. Long et al. (2012) have evaluated the Odyssey calibrations for a number of sites with different depths, albedos and water clarities, which all produced reliable data that matched the standard factory calibrated LI-COR data within $4.5 \%$. Best results, however, would have been obtained performing the calibration at the later measuring site which was, however, not possible due to logistical and practical limitations. After calibration, light loggers were positioned standing upright on iron tripods and secured by SCUBA divers at the respective sites.

\section{Turbidity, salinity and seawater temperature}

Turbidity converted to nephelometric turbidity unit (NTU), salinity (PSU) and water temperature $\left({ }^{\circ} \mathrm{C}\right)$ were measured using a CTD (Sea-Bird, SBE19plus, USA) from 2010 to 2013 (4 years) from 0 to $10 \mathrm{~m}$ depth in each area. Turbidity measures how much light is scattered by suspended particles in the water. The greater the scattering, the higher the turbidity. Therefore, low NTU values indicate high water
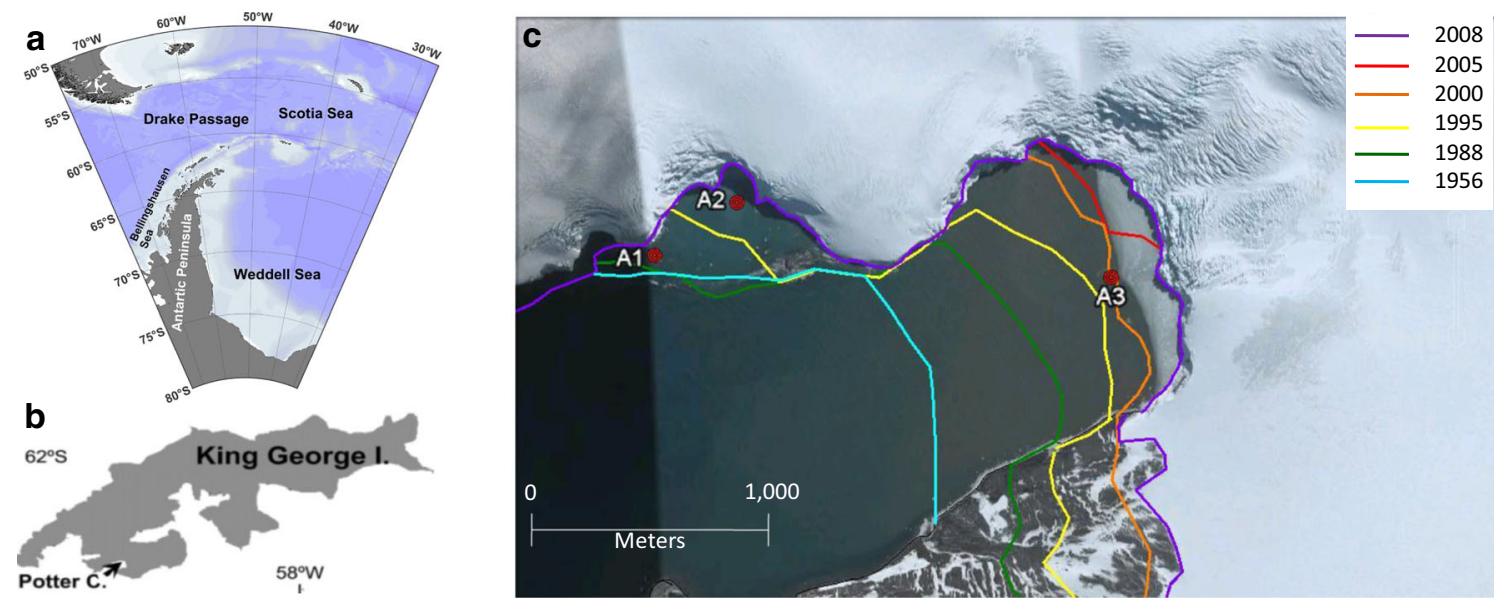

Fig. 1 a Map of the location of 25 de Mayo/King George Island (KGI) on the Western Antarctic Peninsula (arrow), b Potter Cove on KGI (arrow) and c satellite image of inner Potter Cove (Google Earth,
2011) where lines mark the retreat of Fourcade Glacier since 1956 (Rückamp et al. 2011). Dots mark the three newly ice-free areas sampling points ( $A 1$ area 1, $A 2$ area 2, and $A 3$ area 3) 
clarity, while high NTU values indicate low water clarity. In spring and summer, measurements were taken weekly or biweekly, and in autumn once or twice a month depending on meteorological conditions. To represent the shallow water layer, an average from 0.5 to $10 \mathrm{~m}$ depth was done for each variable and for each sampling event.

\section{Algal collection and data analyses}

During the Austral Summer in January 2010, a survey was performed in all areas at 5, 10, 20 and $30 \mathrm{~m}$ depth by SCUBA diving. The endemic Antarctic brown alga $\mathrm{Hi}$ mantothallus grandifolius (A. Gepp and E. S. Gepp) Zinova and the red alga Palmaria decipiens (Reinsch) Ricker were found to be present and abundant in all areas. This survey accounted for the vertical distribution of $\mathrm{H}$. grandifolius present in $\mathrm{A} 1$ from 5 to $30 \mathrm{~m}$ depth, in $\mathrm{A} 2$ from 5 to $20 \mathrm{~m}$ depth and in A3 from 5 to $10 \mathrm{~m}$ depth, and of $P$. decipiens present at $\mathrm{A} 1$ and $\mathrm{A} 2$ from 5 to $20 \mathrm{~m}$ depth and in A3 from 5 to $10 \mathrm{~m}$ depth. Thus, physiological comparisons were performed between 5 and $10 \mathrm{~m}$ depth in all areas.

During January and February 2010, four individuals $(n=4)$ of each species were collected at 5 and $10 \mathrm{~m}$ in all three areas. After collection, all individual thalli were immediately covered by dark plastic bags, brought to the culture room and held in aerated, $0{ }^{\circ} \mathrm{C}$ seawater from the cove. Subsequently, a thallus piece of approximately $0.5 \mathrm{~g}$ was cut from the middle part of the lamina from each replicate (see Arnold and Manley (1985) for methodological considerations about the use of thallus pieces in photosynthetic measurements). Pieces were weighed and kept overnight in the dark in filtered seawater at $0{ }^{\circ} \mathrm{C}$ to avoid wound effects (Drew 1983).

\section{Photosynthetic measurements and parameters}

Photosynthesis and dark respiration were measured in a constantly stirred plastic chamber ( $30 \mathrm{ml}$ volume) fitted with a fiber-optic oxygen mini sensor, connected to an OXY-4 (4 channel Fiber Optic Oxygen Meter, PreSens, Regensburg, Germany). Chambers were filled with filtered sea water from the outer Cove that was buffered with 8 mMTris/NaOH ( $\mathrm{pH} 8.0) ; 5 \mathrm{mM} \mathrm{NaHCO}{ }_{3}$ was added to avoid depletion of inorganic carbon in every chamber during the measuring period. Water was filtered using Whatman GF/F filters with a pore size of $0.7 \mu \mathrm{m}$. The chamber was submerged in a water bath kept at a constant temperature of $2 \pm 0.01{ }^{\circ} \mathrm{C}$ by use of a thermostat (Haake DC3, Karlsruhe, Germany). A slide projector (Leica, Pradovit CA2502, Frankfurt, Germany) was used as light source. Different glass filters (Schott, Mainz, Germany) were used to obtain distinct photon fluence rates measured with a LI-COR LI 1400 datalogger equipped with a LICOR sensor 192SA (LI-COR, Lincoln, USA). Four equal setups were installed and the four individuals of each species (four replicates) measured simultaneously. The dark respiration rate was measured for $20 \mathrm{~min}$, followed by eight different photon fluence rates increasing from 1 to $800 \mu \mathrm{mol}$ photons $\mathrm{m}^{-2} \mathrm{~s}^{-1}\left( \pm 20 \mu \mathrm{mol}\right.$ photon $\mathrm{m}^{-2} \mathrm{~s}^{-1}$ in the four replicates) to measure oxygen production during a period of $10 \mathrm{~min}$ for each photon fluence rate. Photosynthesis versus irradiance curves $(P-I)$ were obtained and used to calculate photosynthetic parameters.

\section{Fitting the models}

Two different models were considered for this study and have been tested to select the best fit to the obtained data:

Model 1: Nonlinear (hyperbolic tangent) function was fitted to the data for each sample (Jassby and Platt 1976). This equation is expressed as

$P=P_{\max } \times \tan h\left(\alpha I / P_{\max }\right)+R$,

Model 2: nonlinear (exponential) function was fitted to the data for each sample (Webb et al. 1974). This equation is expressed as:

$P=P_{\max }\left(1-\exp \left(-\alpha I / P_{\max }\right)+R\right.$,

where $P$ is the photosynthetic rate, $P_{\max }$ is the maximum photosynthetic rate, $\tan h$ is the hyperbolic tangent, exp is the exponential function, $\alpha$ is the initial slope of the curve at low irradiance, $I$ is incident irradiance and $R$ is the dark respiration rate. Accuracy of the curve fit was assessed by nonlinear least square regression at $95 \%$ probability.

\section{Selection criteria for the fitting models}

Two indices were used to select the best fitting curve for the experimental data.

$r^{2}$ was the first index considered to analyze how well the data fits the curve, and it was calculated as Zar (1996).

Akaike information criterion (AIC) was the second index to be considered. AIC is a measure of the relative quality of a statistical model, for a given set of data, and provides a means for model selection (Southwood and Henderson 2000). AIC deals with the trade-off between the goodness of fit of the model and the complexity of the model.

The preferred model is the one with the highest AIC value. The success of the fitting model on our experimental data was judged based on these two indexes, first searching for the highest $r^{2}$ and then for the maximum AIC. The best fitting model was chosen to analyze the experimental data, 
while the other was used first to compare statistical results and trends with the results obtained with the best fitting curve, and secondly for comparisons between estimates of $P_{\max }, \alpha$ and carbon balance (CB) calculated with the two selected models of the photosynthesis versus irradiance curves. $I_{\mathrm{k}}$ (the light saturation point) of photosynthesis was calculated as $\alpha / P_{\max }$ and $I_{\mathrm{c}}$ (the light compensation point) as the intersection of $\alpha$ and the irradiance axis.

\section{Calculations of daily irradiance and estimated metabolic carbon balance}

The continuous PAR data ( $\mu \mathrm{mol}$ photons $\mathrm{m}^{-2} \mathrm{~s}^{-1}$ ) were plotted against time of the day (every $15 \mathrm{~min}$ ) for 5, 10, 20 and $30 \mathrm{~m}$ depth for areas A1, A2 and A3. Calculations of daily net carbon balance $(\mathrm{CB})\left(\mathrm{mg} \mathrm{C} \mathrm{g}^{-1} \mathrm{FW} \mathrm{d}^{-1}\right)$ were performed by including the obtained photosynthetic parameters and incident irradiances into both models of curves,

1. $P=P_{\max } \times \tan h\left(\alpha\left(\right.\right.$ average $\left.\left.(I 1: I 2) / P_{\max }\right)\right)+R$

2. $P=P_{\max }\left(1-\exp \left(-\alpha\left(\operatorname{average}(I 1: I 2) / P_{\max }\right)\right)+R\right.$

"average (I1:I2)" is the average of two incident irradiances between time 1 and time 2 (in situ light measurements of 15 min intervals were considered). Each light intensity value is the average of seven continuous days of PAR measurements. The formulas provide the oxygen production produced every $15 \mathrm{~min}$. Hence, the addition of the $P$ values of each of the 96 intervals obtained during $24 \mathrm{~h}$ results is an approximation of the net oxygen production in an entire day. Calculations of daily net carbon balance ( $\mathrm{mg} \mathrm{C} \mathrm{g}^{-1} \mathrm{FW} \mathrm{d} \mathrm{d}^{-1}$ ) were obtained by converting oxygen data to equivalent carbon units using the ratio $\mathrm{gC}=0.375 \times \mathrm{gO}_{2}$ (see Muscatine 1980). The inclusion of in situ and continuous-light measurement results is a novel and more accurate approximation of the $\mathrm{CB}$ for each species at each depth and area.

\section{Statistical treatment}

General linear model (ANOVA) was performed to test for the effects of the area on the light attenuation coefficient $\left(K_{\mathrm{d}}\right)$ and to test for the effects of area and depth (5 and $10 \mathrm{~m}$ depth) for each species and for each photosynthetic parameter. Homogeneity of variances was checked using Cochran's Test. Post hoc multiple means comparisons were analyzed using DGC test and performed with Infostat 2008 software package (Di Rienzo et al. 2008). Nonparametric Kruskal-Wallis one-way ANOVA test was performed to test the effect of the area on the turbidity, salinity and sea water temperature in each season and the entire year, and in each area separately to test the effects of season on the same variables with the Infostat 2008 software package (Di Rienzo et al. 2008). Significance level was considered for $p<0.05$.

\section{Results}

\section{Underwater quantum irradiance}

The vertical light attenuation coefficient $\left(K_{\mathrm{d}}\right)$ was different among the three areas (Fig. 2a, b). Between 0 and $30 \mathrm{~m}$, and between 0 and $10 \mathrm{~m}$ depth, $K_{\mathrm{d}}$ was significantly higher in A3 compared with A1 and A2 (General Linear Model, $p<0.05$, DGC test). This is also reflected in the continuous-light data from January 2010. Not only was the intensity of PAR reaching the algae different but also the daily exposure time to PAR differed among areas (Fig. 3). In A1, at $5 \mathrm{~m}$ depth, macroalgae were exposed to PAR for $18 \mathrm{~h}$ (mean daily irradiance of $83 \mu \mathrm{mol}$ photons $\mathrm{m}^{-2} \mathrm{~s}^{-1}$ ), in A2 for $17 \mathrm{~h}$ (mean daily irradiance of $60.6 \mu \mathrm{mol}$ photons $\mathrm{m}^{-2} \mathrm{~s}^{-1}$ ) and in $\mathrm{A} 3$ for $12 \mathrm{~h}$ (mean daily irradiance of $22.2 \mu \mathrm{mol}$ photons $\mathrm{m}^{-2} \mathrm{~s}^{-1}$ ) (Fig. 3). Also, the daily exposure time to sunlight decreased with increasing depths (Fig. 3).

\section{Turbidity, salinity and sea water temperature}

Turbidity was significantly higher in summer and autumn compared with winter and spring and generally increases from A1 to A3, but not in winter when there were no
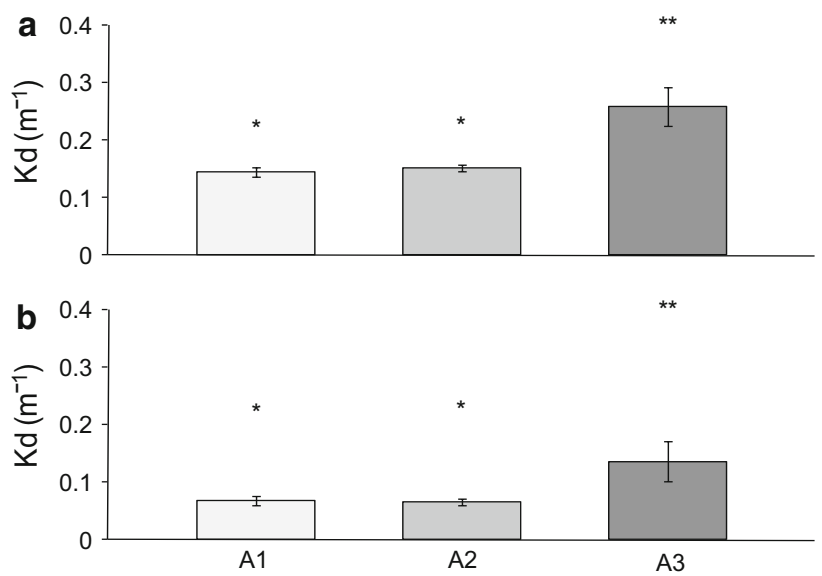

Fig. 2 Light attenuation coefficient $\left(K_{\mathrm{d}}\right)$ in Area $1(A 1)$, Area $2(A 2)$ and Area 3 (A3) in summer (December 2009 to March 2010). Photosynthetic active radiation (PAR) was measured weekly at noon (units: $\mu \mathrm{mol} \mathrm{m} \mathrm{m}^{-2} \mathrm{~s}^{-1}$ ). $K_{\mathrm{d}}$ was calculated measuring the irradiance at $0 \mathrm{~m}$ just below the water surface and the irradiance at $30 \mathrm{~m}$ depth (a), and measuring the irradiance at $0 \mathrm{~m}$ just below the water surface and the irradiance at $10 \mathrm{~m}$ depth (b). Asterisk marks significant differences between areas 

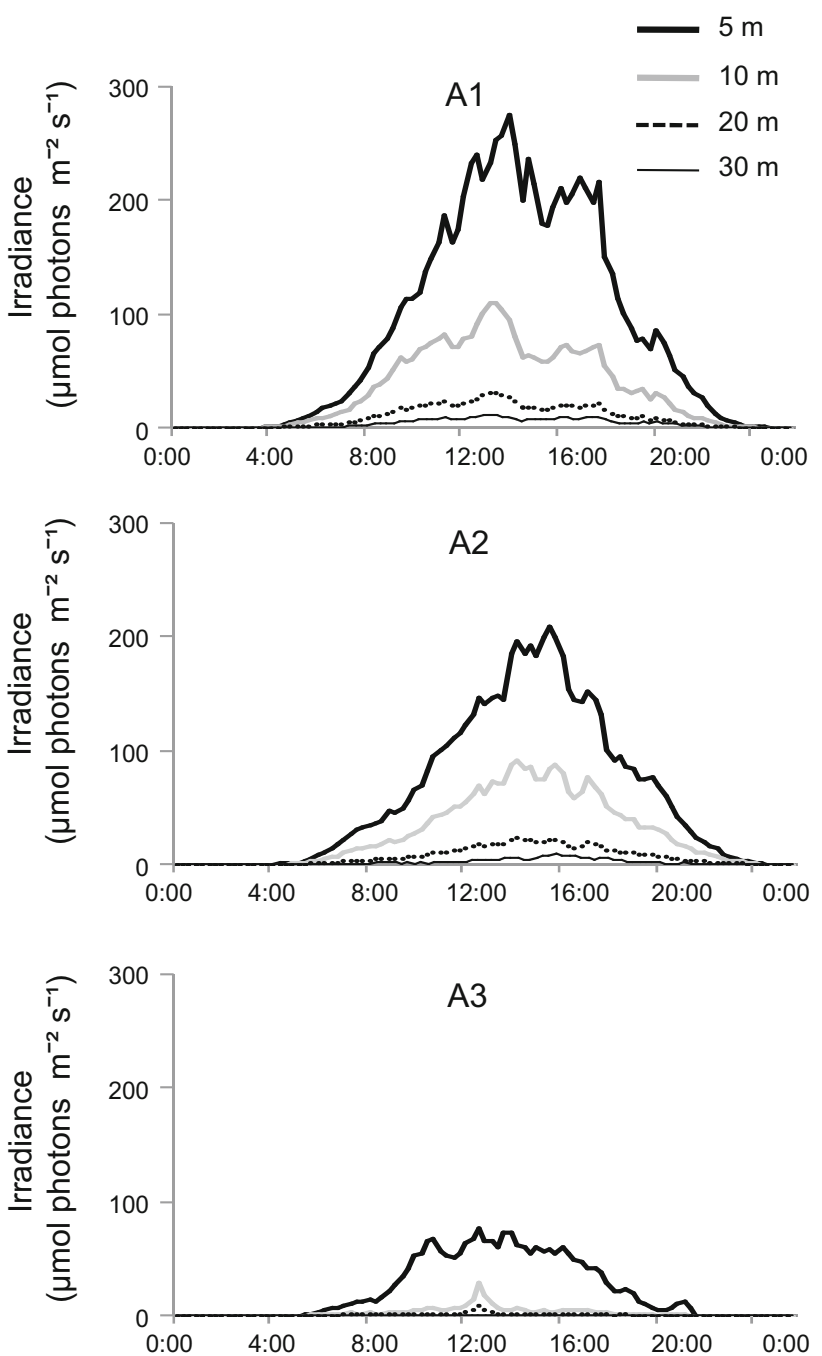

Fig. 3 Daily course of irradiance in Area 1 (A1), Area 2 (A2) and Area $3(A 3)$ at four different depths $(5,10,20$ and $30 \mathrm{~m})$ between 15 and 22 January 2010 (data were averaged over 7 continuous days)

differences among areas (Kruskal-Wallis ANOVA, $p<0.05$, Table 1). During the whole year, salinity was significantly lower in A2 and A3 compared with A1 (Kruskal-Wallis ANOVA, $p<0.05$, Table 1). Overall, for all areas, sea water temperature was similar but was significantly higher in summer compared with the rest of the seasons (Kruskal-Wallis ANOVA, $p<0.05$, Table 1).

\section{Vertical distribution and photosynthetic performance}

The red alga $P$. decipiens was present at 5 and $10 \mathrm{~m}$ depth in $\mathrm{A} 1$, whereas the brown alga $H$. grandifolius was present at all sampled depths $(5,10,20$ and $30 \mathrm{~m}$ depth). In A2, both species were present at $5 \mathrm{~m}$, at 10 and $20 \mathrm{~m}$ depth, while in $\mathrm{A} 3$ both species were present at 5 and $10 \mathrm{~m}$ depth.
According to the values of $r^{2}$ and AIC, model 1 (hyperbolic tangent, Jassby and Platt 1976) was superior to model 2 (exponential, Webb et al. 1974) for our experimental data. Therefore, the respective values of the figures shown were calculated with the hyperbolic tangent fitting curve. For comparative reasons, the respective calculations and statistics are also shown for the exponential model (Tables 2, 3).

Figure 4 shows an example of the photosynthesis-irradiance $(P-I)$ curves determined for both species. Generally, the oxygen production under light saturation is lower in $H$. grandifolius than in $P$. decipiens. Both the species did not show any sign of photoinhibition even under highest irradiances of $800 \mu \mathrm{mol}$ photons $\mathrm{m}^{-2} \mathrm{~s}^{-1}$.

Overall, no significant differences were found between depth, area and the interaction of depth and area for $P_{\max }, \alpha, I_{\mathrm{c}}$ and respiration in both species (General Linear Model, $p<0.05$, DGC test, Table 1). $P_{\max }$ values of $P$. decipiens varied between 38.9 and $80.1 \mu \mathrm{mol} \mathrm{O}_{2} \mathrm{~g}^{-1} \mathrm{FW} \mathrm{h}^{-1}$ and were generally (but not significantly) higher at $5 \mathrm{~m}$ (mean of areas 74. $5 \mu \mathrm{mol} \mathrm{O} \mathrm{g}^{-1} \mathrm{FW} \mathrm{h}^{-1}$ ) compared with $10 \mathrm{~m}$ (mean of areas $60 \mu \mathrm{mol} \mathrm{O}{ }_{2} \mathrm{~g}^{-1} \mathrm{FW} \mathrm{h}^{-1}$, Table 3; Fig. 5). $P_{\max }$ values for $H$. grandifolius varied between 16.2 and $79.2 \mu \mathrm{mol}$ $\mathrm{O}_{2} \mathrm{~g}^{-1} \mathrm{FW} \mathrm{h}{ }^{-1}$ and were increasing with depth in $\mathrm{A} 1$ and $\mathrm{A} 2$, and decreasing with depth in A3 (Table 3; Fig. 5). Respiration rates for $P$. decipiens varied between -10.11 and $-22.02 \mu \mathrm{mol}$ $\mathrm{O}_{2} \mathrm{~g}^{-1} \mathrm{FW} \mathrm{h}{ }^{-1}$ and were usually lower at $10 \mathrm{~m}$ (mean of areas $-20 \mu \mathrm{mol} \mathrm{O}_{2} \mathrm{~g}^{-1} \mathrm{FW} \mathrm{h}^{-1}$ ) than at $5 \mathrm{~m}$ depth (mean of areas $-12.6 \mu \mathrm{mol} \mathrm{O}_{2} \mathrm{~g}^{-1} \mathrm{FW} \mathrm{h}^{-1}$, Fig. 5). Respiration values of $H$. grandifolius varied between -7.01 and $-21.07 \mu \mathrm{mol}$ $\mathrm{O}_{2} \mathrm{~g}^{-1} \mathrm{FW} \mathrm{h}{ }^{-1}$, and did not show a consistent trend between 5 and $10 \mathrm{~m}$ depth or between the areas (Table 3; Fig. 5).

Photosynthetic efficiency $(\alpha)$ of $P$. decipiens varied between 0.58 and $1.08 \mu \mathrm{mol} \mathrm{O}_{2} \mathrm{~g}^{-1} \mathrm{FW} \mathrm{h}^{-1} / \mu$ mol photons $\mathrm{m}^{-2} \mathrm{~s}^{-1}$ and of $H$. grandifolius between 0.47 and $1.83 \mu \mathrm{mol}$ $\mathrm{O}_{2} \mathrm{~g}^{-1} \mathrm{FW} \mathrm{h} \mathrm{h}^{-1} / \mu \mathrm{mol}$ photons $\mathrm{m}^{-2} \mathrm{~s}^{-1}$ and did not show a consistent trend between depths or between the areas (Fig. 6a). The saturation point $\left(I_{\mathrm{k}}\right)$ for $P$. decipiens varied between 55 and $145 \mu \mathrm{mol}$ photons $\mathrm{m}^{-2} \mathrm{~s}^{-1}$ and was similar between areas and depths (Fig. 6b). In $H$. grandifolius, $I_{\mathrm{k}}$ varied between 24.3 and $134 \mu \mathrm{mol}$ photons $\mathrm{m}^{-2} \mathrm{~s}^{-1}$ and was significantly lower at $5 \mathrm{~m}$ (mean of areas $69.6 \mu \mathrm{mol}$ photons $\mathrm{m}^{-2} \mathrm{~s}^{-1}$ ) than at $10 \mathrm{~m}$ depth (mean of areas $110 \mu \mathrm{mol}$ photons $\mathrm{m}^{-2} \mathrm{~s}^{-1}$ ) (General Linear Model, $p<0.05$, DGC test) (Fig. $6 \mathrm{~b}$ ). The compensation point $\left(\mathrm{I}_{\mathrm{c}}\right)$ for $P$. decipiens varied between 18 and $29 \mu$ mol photons $\mathrm{m}^{-2} \mathrm{~s}^{-1}$ and of $H$. grandifolius between 14 and $41 \mu \mathrm{mol}$ photons $\mathrm{m}^{-2} \mathrm{~s}^{-1}$ (Fig. 6c).

\section{Algal light requirements and estimated metabolic carbon balance}

For $P$. decipiens, daily metabolic carbon balance (CB) varied significantly among areas and depths (General 
Table 1 Turbidity (NTU), salinity (PSU) and temperature $\left({ }^{\circ} \mathrm{C}\right)$ for Areas 1,2 and 3

\begin{tabular}{lccccr}
\hline & \multicolumn{1}{l}{ Autumn } & Winter & \multicolumn{1}{l}{ Spring } & \multicolumn{1}{l}{ Summer } & \multicolumn{1}{c}{ Entire year } \\
\hline Area 1 & & & & & \\
Turbidity (NTU) & $0.56( \pm 0.15)$ & $0.34( \pm 0.1)$ & $0.71( \pm 0.13)$ & $1.25( \pm 0.32)$ & $0.84( \pm 0.15)$ \\
Salinity (PSU) & $34.03( \pm 0.1)$ & $34.2( \pm 0.14)$ & $34.2( \pm 0.13)$ & $33.94( \pm 0.1)$ & $34.07( \pm 0.06)$ \\
Temperature $\left({ }^{\circ} \mathrm{C}\right)$ & $-0.02( \pm 0.38)$ & $-1.35( \pm 0.22)$ & $-0.17( \pm 0.32)$ & $1.27( \pm 0.17)$ & $0.29( \pm 0.22)$ \\
Area 2 & & & & & \\
Turbidity (NTU) & $2.79( \pm 0.93)$ & $0.57( \pm 0.09)$ & $1.42( \pm 0.5)$ & $3.49( \pm 0.86)$ & $2.39( \pm 0.44)$ \\
Salinity (PSU) & $33.87( \pm 0.14)$ & $33.2( \pm 0.91)$ & $34.01( \pm 0.06)$ & $33.66( \pm 0.14)$ & $33.7( \pm 0.09)$ \\
Temperature $\left({ }^{\circ} \mathrm{C}\right)$ & $-0.08( \pm 0.39)$ & $-1.61( \pm 0.03)$ & $-0.01( \pm 0.34)$ & $1.4( \pm 0.21)$ & $0.31( \pm 0.24)$ \\
Area 3 & & & & & \\
Turbidity (NTU) & $5.7( \pm 1.49)$ & $1.04( \pm 0.06)$ & $3.62( \pm 1.41)$ & $7.52( \pm 2.21)$ & $5.1( \pm 0.1)$ \\
Salinity (PSU) & $33.65( \pm 0.22)$ & $32.53( \pm 0.3)$ & $33.88( \pm 0.07)$ & $32.76( \pm 0.71)$ & $33.35( \pm 0.25)$ \\
Temperature $\left({ }^{\circ} \mathrm{C}\right)$ & $-0.19( \pm 0.42)$ & $-1.74( \pm 0.08)$ & $0.01( \pm 0.3)$ & $1.36( \pm 0.183)$ & $0.24( \pm 0.25)$ \\
\hline
\end{tabular}

Values represent 2010-2013 means from the superficial layer (0-10 m) for each season $( \pm$ SE). Numbers in italic indicate significant results between areas for each season or year $(p<0.05)$
Table 2 Effects of area and depth on net photosynthesis $\left(P_{\max }\right)$, photosynthetic efficiency $(\alpha)$, saturation point $\left(I_{\mathrm{k}}\right)$, respiration (Resp) and daily metabolic carbon balance $(\mathrm{CB})$ on $P$. decipiens and $H$. grandifolius

\begin{tabular}{|c|c|c|c|c|c|}
\hline & $P_{\max }$ & $\alpha$ & $I_{\mathrm{k}}$ & Resp & $\mathrm{CB}$ \\
\hline \multicolumn{6}{|l|}{ (a) $P$. decipiens } \\
\hline Area & 0.075 & 0.401 & 0.901 & 0.732 & 0.000 \\
\hline Depth & 0.091 & 0.804 & 0.217 & 0.398 & 0.001 \\
\hline Area $\times$ depth & 0.499 & 0.253 & 0.482 & 0.076 & 0.765 \\
\hline \multicolumn{6}{|l|}{ H. grandifolius } \\
\hline Area & 0.608 & 0.073 & 0.363 & 0.522 & 0.007 \\
\hline Depth & 0.131 & 0.148 & 0.041 & 0.971 & 0.034 \\
\hline Area $\times$ depth & 0.127 & 0.222 & 0.093 & 0.290 & 0.039 \\
\hline Species & 0.00 & 0.306 & 0.363 & 0.131 & 0.142 \\
\hline \multicolumn{6}{|l|}{ (b) P. decipiens } \\
\hline Area & 0.081 & 0.289 & 0.998 & 0.383 & 0.000 \\
\hline Depth & 0.077 & 0.371 & 0.214 & 0.624 & 0.004 \\
\hline Area $\times$ depth & 0.539 & 0.290 & 0.421 & 0.074 & 0.729 \\
\hline \multicolumn{6}{|l|}{ H. grandifolius } \\
\hline Area & 0.594 & 0.249 & 0.317 & 0.601 & 0.008 \\
\hline Depth & 0.138 & 0.549 & 0.107 & 0.791 & 0.076 \\
\hline Area $\times$ depth & 0.128 & 0.166 & 0.129 & 0.259 & 0.230 \\
\hline Species & 0.003 & 0.366 & 0.302 & 0.123 & 0.292 \\
\hline
\end{tabular}

Numbers in italic indicate significant $(p<0.05)$ results. (a) Estimates obtained with model 1 (hyperbolic tangent fitting curve). (b) Estimates obtained with model 2 (exponential fitting curve)

Linear Model, $p<0.05$; Fig. 7); CB was significantly higher in $\mathrm{A} 1$ (means of depths $4.48 \mathrm{mg} \mathrm{C} \mathrm{g}^{-1} \mathrm{FW} \mathrm{d}^{-1}$ ) and $\mathrm{A} 2$ (means of depths $2.30 \mathrm{mg} \mathrm{C} \mathrm{g}^{-1} \mathrm{FW} \mathrm{d}^{-1}$ ) compared with $\mathrm{A} 3$ (means of depths $-1.99 \mathrm{mg} \mathrm{C} \mathrm{g}^{-1} \mathrm{FW} \mathrm{d}^{-1}$ ), and significantly higher at $5 \mathrm{~m}$ depth (mean of areas $3.55 \mathrm{mg} \mathrm{C} \mathrm{g}^{-1} \mathrm{FW} \mathrm{d}{ }^{-1}$ ) compared with $10 \mathrm{~m}$ depth (mean of areas $-0.47 \mathrm{mg} \mathrm{C} \mathrm{g}^{-1} \mathrm{FW} \mathrm{d}^{-1}$ ). A significant interaction between areas and depths was found in $H$. grandifolius. $\mathrm{CB}$ was significantly lower in $\mathrm{A} 3$ at $5 \mathrm{~m}\left(-0.65 \mathrm{mg} \mathrm{C} \mathrm{g}^{-1} \mathrm{FW}\right.$ $\left.\mathrm{d}^{-1}\right)$ and $10 \mathrm{~m}\left(-2.76 \mathrm{mg} \mathrm{C} \mathrm{g}^{-1} \mathrm{FW} \mathrm{d}^{-1}\right)$ and in $\mathrm{A} 2$ at $10 \mathrm{~m}$ depths $\left(-1.26 \mathrm{mg} \mathrm{C} \mathrm{g}^{-1} \mathrm{FW} \mathrm{d}^{-1}\right)$ compared with the rest of areas and depths where it varied between 0.84 and $2.83 \mathrm{mg}$ $\mathrm{C} \mathrm{g}^{-1} \mathrm{FW} \mathrm{d}^{-1}$ (General Linear Model, $p<0.05$; Tables 2, 3; Fig. 7).

Statistical results and patterns between species, areas and depths were sometimes different depending on the selected fitting model (hyperbolic tangent or exponential) (Table 2a, b). Overall, results performed with model 2 showed no significant differences for $P$. decipiens (Table 2b). However, for $H$. grandifolius, only area had a significant effect on $\mathrm{CB}$ which was significantly higher in $\mathrm{A} 1$ and $\mathrm{A} 2$ compared with A1. $I_{\mathrm{k}}$ was similar between depths for this species (Table 2b). Statistical results with estimates obtained with model 2 (exponential fitting curve) (General Linear Model, $p<0.05$ ) are shown in Table 2. In addition, some values computed with the same data sets were sometimes very different according to the chosen model. As an example, comparisons of $P_{\max }, \alpha, I_{\mathrm{k}}$ and CB were conducted for models 1 and 2 and for Area 1 and Area 3 , and differences were found mainly for $\alpha$ and $I_{\mathrm{k}}$ values (Table 3 Model 1 and 2).

\section{Discussion}

The results of this study show that macroalgae colonize and persist in newly ice-free areas in Potter Cove as also reported by Quartino et al. (2013). Photosynthetic performance of both tested species did not show any acclimation to areas with more turbid waters resulting in lower light conditions at greater depths. The differences in CB values in the different depths and areas are therefore only 
Table $3 P_{\text {max }}$ : net photosynthesis $\left(\mu \mathrm{mol} \mathrm{O}_{2} \mathrm{~g}^{-1} \mathrm{FW} \mathrm{h}^{-1}\right.$ ), $\alpha$ : photosynthetic efficiency $\left(\mu \mathrm{mol} \mathrm{O} \mathrm{g}^{-1} \mathrm{FW} \mathrm{h}-1 / \mu \mathrm{mol}\right.$ photons $\left.\mathrm{m}^{-2} \mathrm{~s}^{-1}\right), I_{\mathrm{k}}$ : saturation point of photosynthesis $\left(\mu \mathrm{mol}\right.$ photons $\left.\mathrm{m}^{-2} \mathrm{~s}^{-1}\right)$ and $\mathrm{CB}$ : daily metabolic carbon balance $\left(\mathrm{mg} \mathrm{C} \mathrm{g}^{-1} \mathrm{FW} \mathrm{d}^{-1}\right.$ ) calculated for
Model 1 (Jassby and Platt 1976) and Model 2 (Webb et al. 1974) at different depth and areas; $\mathrm{Pd}$ : $P$. decipiens and $\mathrm{Hg}$ : $H$. grandifolius $\pm \mathrm{SE}$

\begin{tabular}{|c|c|c|c|c|c|c|c|c|}
\hline & \multicolumn{4}{|l|}{ Model 1} & \multicolumn{4}{|l|}{ Model 2} \\
\hline & $\operatorname{Pd} 5 \mathrm{~m}$ & $\mathrm{Pd} 10 \mathrm{~m}$ & $\mathrm{Hg} 5 \mathrm{~m}$ & $\mathrm{Hg} 10 \mathrm{~m}$ & Pd $5 \mathrm{~m}$ & $\mathrm{Pd} 10 \mathrm{~m}$ & $\mathrm{Hg} 5 \mathrm{~m}$ & $\mathrm{Hg} 10 \mathrm{~m}$ \\
\hline \multicolumn{9}{|l|}{ Area 1} \\
\hline$P_{\max }$ & $77.0( \pm 2.1)$ & $69.7( \pm 4.2)$ & $16.2( \pm 14.6)$ & $78.3( \pm 4.8)$ & $77.9( \pm 10)$ & $68.8( \pm 16.5)$ & $16.6( \pm 5.1)$ & $79.2( \pm 12.3)$ \\
\hline$A$ & $0.8( \pm 0.2$ & $1.1( \pm 0.2)$ & $1.8( \pm 1.3)$ & $0.7( \pm 0.1)$ & $1.2( \pm 0.2)$ & $3.0( \pm 1.6)$ & $2.4( \pm 0.2)$ & $1.0( \pm 0.2)$ \\
\hline$I_{\mathrm{k}}$ & $145( \pm 43.1)$ & $87.6( \pm 11.6)$ & $33.4( \pm 18.6)$ & $134(16.8)$ & $107( \pm 36.8)$ & $55( \pm 15.7)$ & $24.3( \pm 12.5)$ & $98.4( \pm 11.1)$ \\
\hline $\mathrm{CB}$ & $5.2( \pm 1.5)$ & $1.9( \pm 0.8)$ & $0.7( \pm 1.5)$ & $1.5( \pm 0.4)$ & $7.4( \pm 1.5)$ & $2.9( \pm 1.1)$ & $2.1( \pm 1.5)$ & $2.3( \pm 0.3)$ \\
\hline \multicolumn{9}{|l|}{ Area 2} \\
\hline$P_{\max }$ & $66.9( \pm 4.6)$ & $38.9( \pm 3.4)$ & $25.6( \pm 2.1)$ & $36.1( \pm 3.2)$ & $67.8( \pm 4.7)$ & $39.4( \pm 4.6)$ & $25.9( \pm 13.2)$ & $35.8( \pm 18.7)$ \\
\hline$A$ & $0.8( \pm 0.1)$ & $0.6( \pm 0.2)$ & $0.5( \pm 0.2)$ & $0.5( \pm 0.2)$ & $1.2( \pm 0.2)$ & $0.8( \pm 0.3)$ & $0.7( \pm 0.2)$ & $1.4( \pm 0.6)$ \\
\hline$I_{\mathrm{k}}$ & $133.1( \pm 11.6)$ & $103.2( \pm 31.3)$ & $61.3( \pm 34.4)$ & $98.6( \pm 10)$ & $81.2( \pm 9.4)$ & $81.6( \pm 22.3)$ & $47.1( \pm 13.7)$ & $59.2( \pm 17.1)$ \\
\hline $\mathrm{CB}$ & $2.9( \pm 1)$ & $0.7( \pm 0.1)$ & $2.2( \pm 1)$ & $-1( \pm 0.4)$ & $0.6( \pm 0.1)$ & $0.8( \pm 0.1)$ & $2.6( \pm 1.2)$ & $-0.9( \pm 0.5)$ \\
\hline \multicolumn{9}{|l|}{ Area 3} \\
\hline$P_{\max }$ & $78.5( \pm 2.1)$ & $71.3( \pm 3.9)$ & $45.6( \pm 5.4)$ & $36.6( \pm 1.8)$ & $80.1( \pm 7.3)$ & $72.0( \pm 7.3)$ & $46.2( \pm 19.7)$ & $37.1( \pm 2.2)$ \\
\hline$A$ & $0.8( \pm 0.1)$ & $0.9( \pm 0.1)$ & $0.6( \pm 0.2)$ & $0.5( \pm 0.1)$ & $1.1( \pm 0.1)$ & $1.3( \pm 0.2)$ & $0.8( \pm 0.3)$ & $0.7( \pm 0.1)$ \\
\hline$I_{\mathrm{k}}$ & $113.1( \pm 12.3)$ & $103.5( \pm 15.3)$ & $115.7( \pm 34.2)$ & $104.7( \pm 13.4)$ & $88.5( \pm 7.1)$ & $76.1( \pm 13.3)$ & $84.3( \pm 25.7)$ & $77.8( \pm 10.7)$ \\
\hline $\mathrm{CB}$ & $0.2( \pm 0.4)$ & $-3.4( \pm 0.9)$ & $-0.5( \pm 0.5)$ & $-2.2( \pm 0.4)$ & $-0.8( \pm 0.4)$ & $-6.4( \pm 1.1)$ & $-1.5( \pm 0.6)$ & $-3.2( \pm 0.4)$ \\
\hline
\end{tabular}
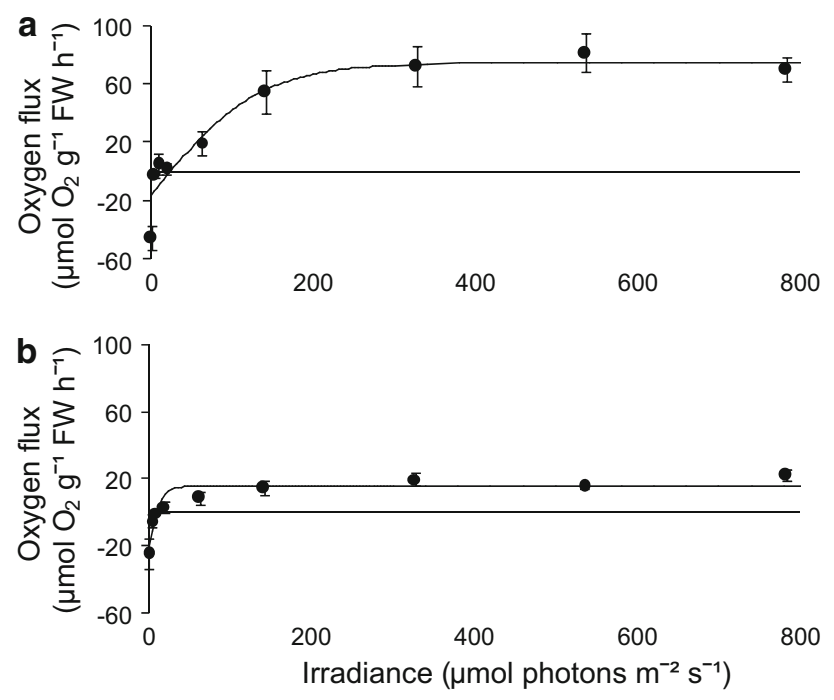

Fig. 4 Photosynthesis-light $(P-I)$ curves of $P$. decipiens (a) and $H$. grandifolius $(\mathbf{b})$ in Area 1 at $5 \mathrm{~m}$ depth. Points represent mean $\pm \mathrm{SD}$ of four measurements. See text for details of curve fitting

dependent on the incoming light. The maximal depth distribution limit of macroalgae was positively correlated to the light penetration during summer which increases with the distance to the glacier. These results are consistent with another study showing that the lower distribution limit primarily depends on the availability of PAR (Gómez et al. 1997, reviewed in Gómez et al. 2009).
In Potter Cove, high concentrations of sedimentary runoff are produced during the summer melting season (Eraso and Domínguez 2007), and this phenomenon is more evident in newly ice-free areas close to the glacial run-off (Quartino et al. 2013). Over the last two decades, there has been an increase in suspended particulate matter in surface waters of the inner cove in spring-summer (Schloss et al. 2012). In the present study, it is also shown that the inflow of sediment during the warmer months leads to marked seasonal variations in turbidity with high levels also in autumn, and significant turbidity differences between areas. The amount of sediment input and the period when this phenomenon occurs are extremely relevant for seaweeds as favorable light conditions for algal growth are constrained to only 2 or 3 months a year, and they prevail until the turbid melt water enters the water column (Wiencke and Amsler 2012). On the other hand, it must also be considered that an increase in sediment input during the warmer months can have positive effects in reducing exposure to excessive ultraviolet radiation $(280-400 \mathrm{~nm})$ with potentially damaging effects (Bischof et al. 1998; Campana et al. 2009; Zacher et al. 2009). Sediment input during spring and summer could also have beneficial effects by attenuating high PAR which inhibits the recruitment of macroalgal species (Graham 1996; Hanelt et al. 1997). Nevertheless, this study and others indicate that seaweeds in Potter Cove are not only shade adapted but can also cope with high PAR intensities in summer as they are not 

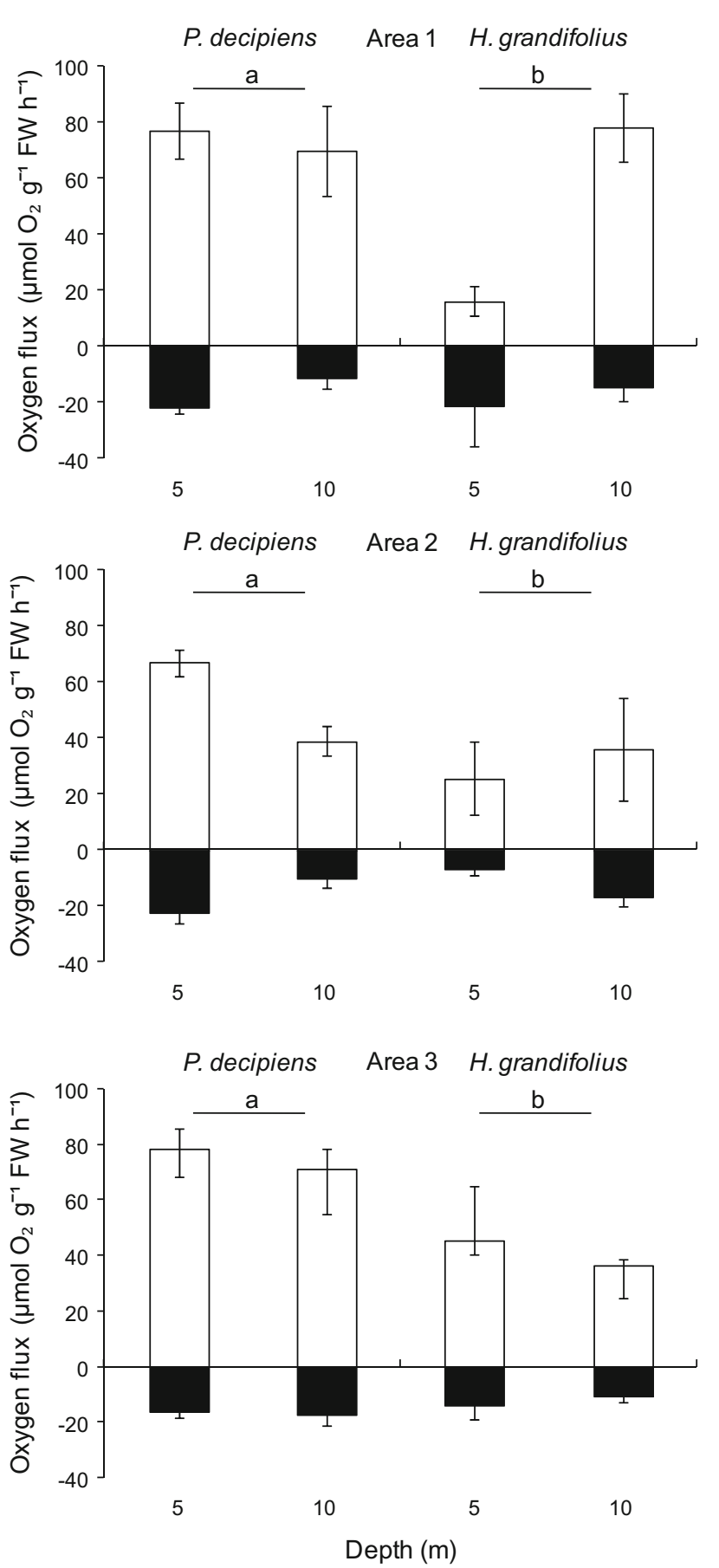

Fig. 5 Net photosynthesis $\left(P_{\max }\right)$ and dark respiration $(R)$ of $P$. decipiens and $H$. grandifolius collected at 5 and $10 \mathrm{~m}$ depth in three (Areas 1, 2 and 3) in Potter Cove. Lower case letters significant $P_{\max }$ differences between $P$. decipiens and $H$. grandifolius (General Linear Model, $p<0.05$ )

photoinhibited even under very high irradiances (Gómez et al. 1997; Wiencke and Amsler 2012).

In Antarctica, irradiance levels seem to determine the vertical distributions at greater depths but not the upper (shallow or nearshore) limits as depth zonation ranges between 0 and $45 \mathrm{~m}$ depth (Quartino and Boraso de Zaixso 2008; Wiencke and Amsler 2012).

In Potter Cove, circulation and wind cause resuspension processes which are also of major importance in limiting light penetration into the water column (Schloss et al. 2012). Furthermore, recent glacier retreat has caused a rise in sediment deposition rates over the last 60 years (Monien et al. 2011). Thus, the inflow of sediment into the marine system not only reduces the light availability for the algal photosynthesis but can lower survival and germination rates directly (Arakawa and Matsuike 1992; Chapman and Fletcher 2002) by burying and preventing the attachment of the spores (Eriksson and Johansson 2005). Quartino et al. (2013) reported the presence of our studied species in areas with high sedimentation and immersed in a sediment layer on the sea bed showing the exceptional ability of these species to survive and successfully reproduce under such conditions. In Potter Cove, rapid glacial melting also results in salinity and temperature changes between areas, seasons and years (Schloss et al. 2012). However, these changes do not stress the photosynthetic performance of macroalgae significantly (Karsten et al. 1991a, b; Eggert and Wiencke 2000; Wiencke and Amsler 2012). Even spores of the brown alga A. utricularis showed no sign of photoinhibition after 4 days of exposure to a salinity of 20 PSU (Zacher, personal communication).

\section{Photosynthesis and daily metabolic carbon balance}

Overall, only the CB values showed significant differences between area and depth in both species. All other photosynthetic parameters $\left(\alpha, I_{\mathrm{k}}, I_{\mathrm{c}}, R\right)$ were non-significant for the tested parameters. None of the two investigated species showed signs of photoinhibition even under the highest irradiance of $800 \mu \mathrm{mol} \mathrm{m} \mathrm{m}^{-2} \mathrm{~s}^{-1}$.

Himantothallus grandifolius is endemic to the Antarctic, and Palmaria decipiens occurs also on sub-Antarctic islands. They are typical season anticipators exhibiting high rates of photosynthesis and growth in late winter/spring (Wiencke et al. 2011). Similar values of the photosynthetic parameters of both species for depth and areas indicate a low acclimation potential of the photosynthesis to different irradiance regimes. Markager and Sand-Jensen (1992) reported similar findings pointing out that species maintain similar photosynthetic performances under a very broad range of different irradiances. Other authors reported a lack of variations of $P_{\max }$ and $\alpha$ with depth also in $H$. grandifolius (Drew and Hastings 1992; Gómez et al. 1997), and in P. decipiens, Gigartina skottsbergii, Trematocarpus antarcticus (formerly: Kallymenia Antarctica) and Desmarestia anceps (Gómez et al. 1997), suggesting that photoacclimatation does not occur in relation to different 

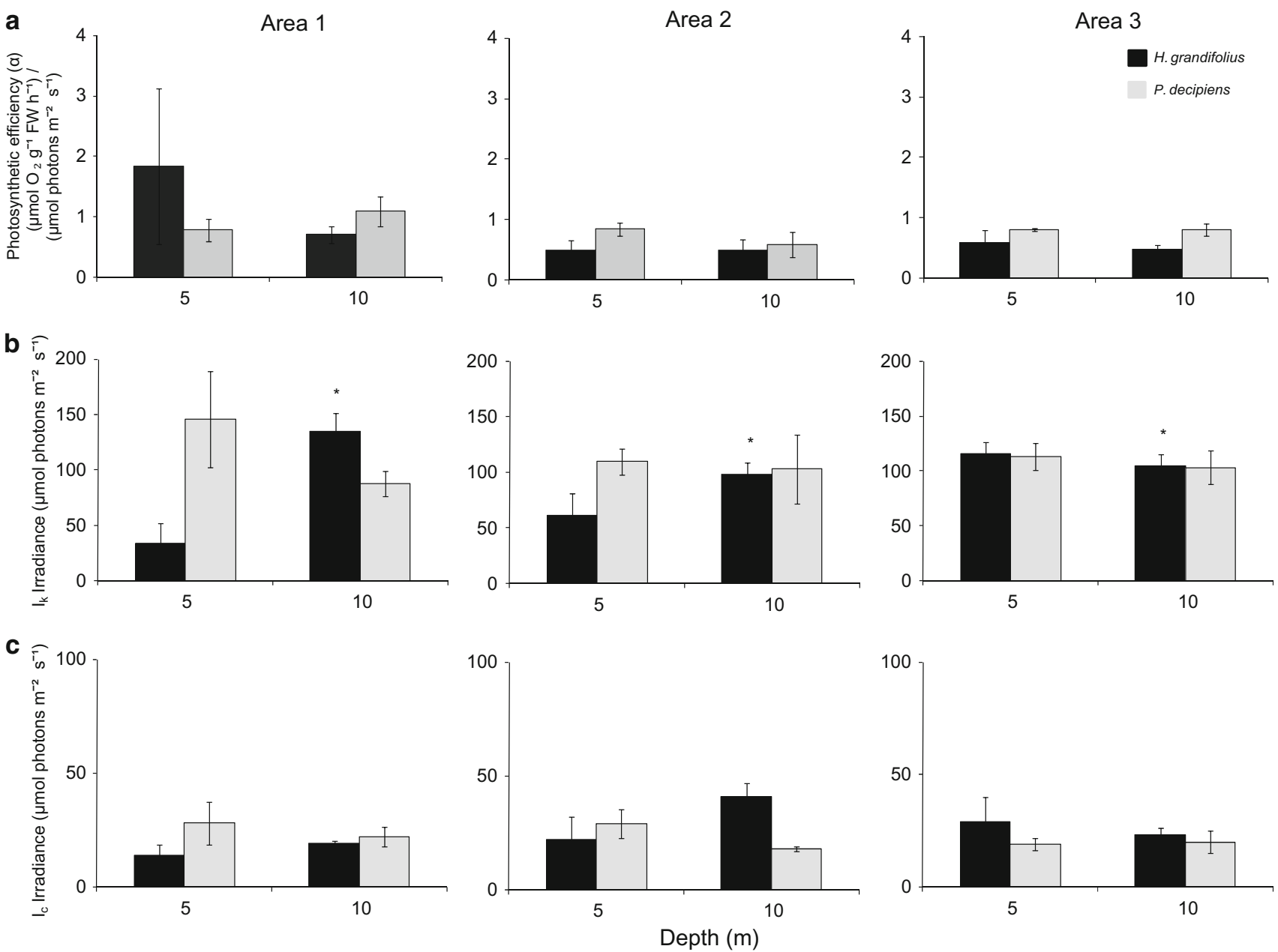

Fig. 6 a Photosynthetic efficiency $(\alpha)$, b saturation point $\left(I_{\mathrm{k}}\right)$ of photosynthesis and $\mathbf{c}$ compensation point $\left(I_{\mathrm{c}}\right)$ of photosynthesis of $P$. decipiens and $H$. grandifolius collected at 5 and $10 \mathrm{~m}$ depths in the

light availabilities. On the other hand, other studies in the Ross Sea in Antarctica with Phyllophora antarctica and Phymatolithon foecundum (Schwarz et al. 2003), and in Greenland with brown macroalgae (Kühl et al. 2001) suggest a greater acclimation potential to low light at deeper depths through lower $I_{\mathrm{c}}, I_{\mathrm{k}}$ and $\mathrm{rETR}_{\max }$. Thus, additional studies are required to elucidate more clearly the depth and area-related patterns. Antarctic seaweeds are frequently characterized as shade-adapted organisms being able to grow under low irradiances with low $I_{\mathrm{k}}$ values and high photosynthetic efficiencies $(\alpha)$, and due to their ability to cope with high-light conditions in summer without photoinhibition (Wiencke 1990a, b; Gómez et al. 1997; reviewed in Gómez et al. 2009; Wiencke and Amsler 2012). However, $P_{\max }$ and respiration rates, $I_{\mathrm{k}}$ and $I_{\mathrm{c}}$ values obtained in this study are higher in comparison with other studies (Gómez et al. 2009). Previous studies performed in Antarctica reported for $P$. decipiens values between 11 and $49 \mu \mathrm{mol}$ photons $\mathrm{m}^{-2} \mathrm{~s}^{-1}$ for $I_{\mathrm{k}}$ and three areas (Areas 1, 2 and 3) in Potter Cove asterisk mark significant differences between depths for $H$. grandifolius (General Linear Model, $p<0.05$ )

6-15 $\mu \mathrm{mol}$ photons $\mathrm{m}^{-2} \mathrm{~s}^{-1}$ for $I_{\mathrm{c}}$, and for H. grandifolius, the values ranged from 22 to $29 \mu \mathrm{mol}$ photons $\mathrm{m}^{-2} \mathrm{~s}^{-1}$ for $I_{\mathrm{k}}$ and 6-8 $\mu$ mol photons $\mathrm{m}^{-2} \mathrm{~s}^{-1}$ for $I_{\mathrm{c}}$ (Drew 1977; Weykam et al. 1996; Gómez et al. 1997). $P_{\max }$ and respiration rates for both species obtained in this study are not comparable, and sometimes double rates were measured compared with other studies (e.g., Gómez et al. 1997). Differences are presumably due to the different equipment used to measure the oxygen production, optodes (our study) and oxygen electrodes (Gómez et al. 1997). In addition, other reasons for the elevated respiration activities may perhaps be a higher presence of bacteria in summer compared with late winter/ spring resulting in higher respiration rates, or due to the differences in microbial cover between the sampling sitesinside Potter Cove in newly free areas (our study) and in the outer side of the Cove with no glacial influence and no strong light attenuation (Gómez et al. 1997).

The carbon balance was the most conclusive parameter to explain and understand the observed zonation patterns. 

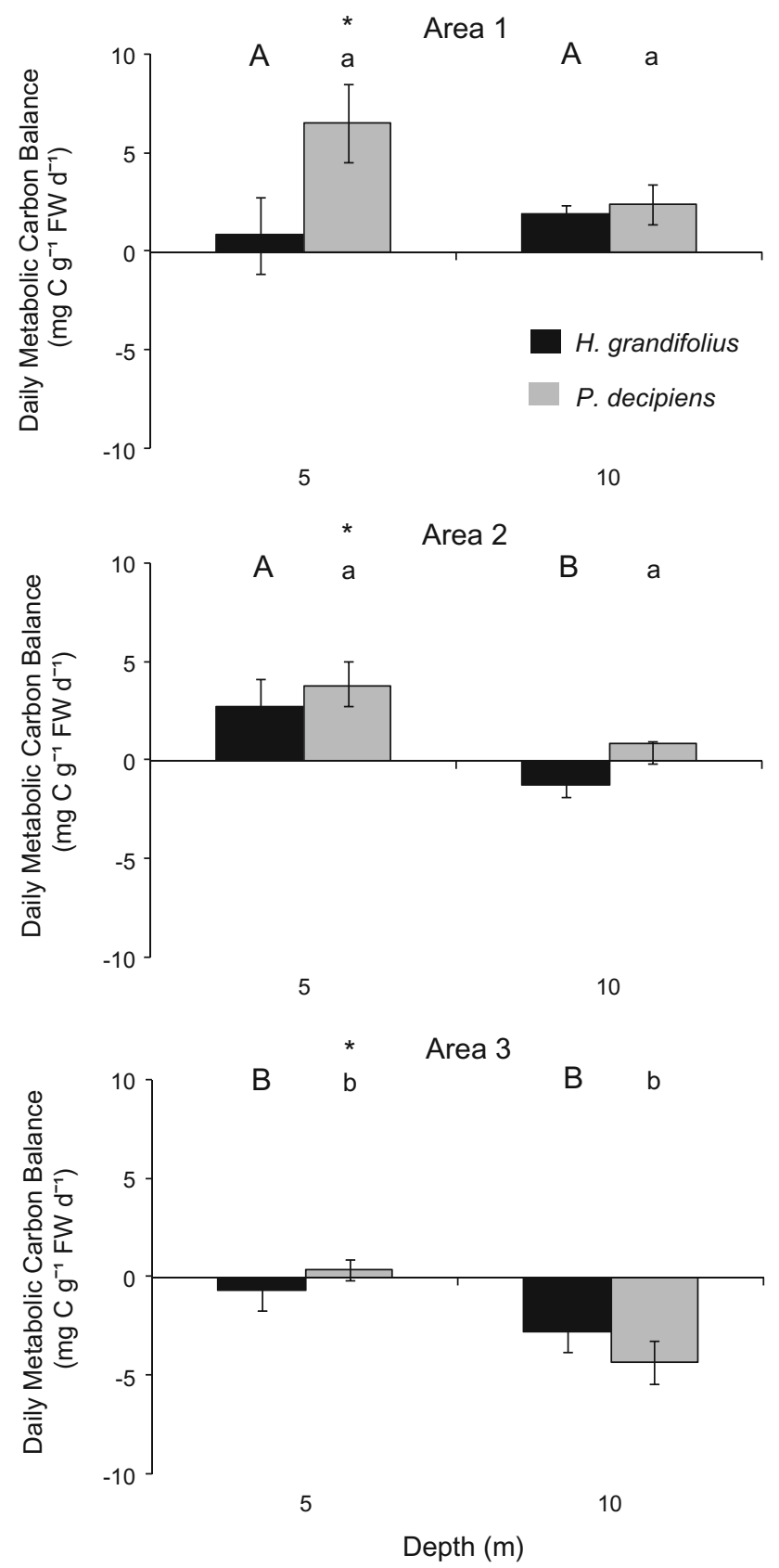

Fig. 7 Daily metabolic carbon balance in Antarctic macroalgae collected at three different newly ice-free areas at different depths at Potter Cove during January-February 2010 (continuous PAR 24-h data approximated and obtained 2009-2010). Values correspond to an overall net gain or loss of $C$ during $24 \mathrm{~h}$. Asterisk mark significant differences between depths for each species (General Linear Model, $p<0.05)$. Lower case letters significant differences for $P$. decipiens among areas, and capital letters for significant differences for $H$. grandifolius between areas and depths

Area and depth had significant effects for $\mathrm{CB}$ in $P$. decipiens, and for $H$. grandifolius, the interaction between area and depth had a significant effect on CB. Gómez et al. (1997) measured CB in the same species but in spring, and results are not fully comparable to this study probably due to the following factors: First, in the present study, the formula used to calculate carbon balance (Jassby and Platt 1976) is different from that (Webb et al. 1974) used by Gómez et al. (1997). Second, aiming to have a more accurate approximation of the $\mathrm{CB}$, the total continuous daily exposure to light measured in situ was included into the formula, whereas Gómez et al. (1997) included only the daily hours of light saturation. Lastly, oxygen data were converted to equivalent carbon units using different ratios: Gómez et al. (1997) used $\mathrm{gC} \mathrm{gO}_{2}=0.3$ (Matta and Chapman 1991), while in this study, the considered ratio was $\mathrm{gC}=0.375 \times \mathrm{gO}_{2}$ (Muscatine 1980).

Negative summer $\mathrm{CB}$ values were measured at greater depths and in areas with high turbidity and raise the question how the algae survive and grow under these conditions. The results presented here are based on a continuous 7-day summer measurement of PAR only. In spring, however, PAR can enter deeper into the water column resulting in positive $\mathrm{CBs}$ which enables the algae to accumulate carbon storage compounds such as reserve carbohydrates (Gómez et al. 1997). Gómez et al. (1997) and Deregibus et al. (unpublished data) measured CB of the same species but in spring, and positive CBs were found for most of the depths. To cope with low- or no-light conditions and thus negative $\mathrm{CB}$ values in summer, macroalgae can use their storage compounds to meet their metabolic needs (Drew and Hastings 1992; Kirst and Wiencke 1995; Wiencke and Amsler 2012). Currently, whole-year PAR continuous measurements are performed to estimate the light climate over a complete year and between years. It is important to highlight that the studied summer was exceptionally cold resulting in less intensive sediment discharge from glacial melt water into the cove (Schloss et al. 2014) and that CB values are even more negative in the following summers (Deregibus et al. unpublished data). Particularly considering that the WAP is one of the most rapidly warming regions on Earth (Turner et al. 2005), we could expect warmer summers associated with lower and even more negative $\mathrm{CB}$ values in areas close to the glacier run-off. On the other hand, it should also be considered that warmer winters and springs could lead to earlier sea ice melting (Schloss et al. 2012, Deregibus et al. unpublished data), causing an abrupt increase in light, probably compensating the reduction in PAR in summer or even significantly increasing the annual light budget for macroalgae (Clark et al. 2013).

\section{Differences between photosynthesis versus irradiance models}

For proper approximation of productivity in marine ecosystems, $P-I$ models need to be accurate when estimating the photosynthetic parameters and describing the 
experimental data (Nelson and Siegrist 1987; Saba et al. 2010; Jones et al. 2014). In our study and for our data sets, Model 1 (hyperbolic tangent, Jassby and Platt 1976) was better suited than model 2 (exponential, Webb et al. 1974) to explain our data because it had a better overall fit, highest AIC and precision in photosynthetic estimates. Both models are commonly used. The Webb equation is ubiquitous in the literature, probably because it is mathematically convenient and generally fits observations well. Jassby and Platt (1976) found that their hyperbolic tangent equation provided the best overall fit to close to 200 observed curves in a comparison of various equations (Jassby and Platt 1976; Jones et al. 2014). Nevertheless, recent studies performed by Jones et al. (2014) recommend that Bannister's model (Bannister 1979) is the most appropriate of existing $P-I$ curve equations. This single model with variable curvature could solve the problem of $P-I$ models with fixed curvatures that although they fit observations well they are not always comparable (Frenette et al. 1993).

Our results show differences between estimates of photosynthetic parameters calculated with two different models of the $P-I$ curves. For example, in the case of $H$. grandifolius when estimates were calculated with model 1 , a significant interaction for CB between areas and depth was found and significant differences with depth for $I_{\mathrm{k}}$. However, when estimates were calculated with model 2, there was only a significant effect on $\mathrm{CB}$ between areas, and $I_{\mathrm{k}}$ was similar between depths for this species. This means that very different conclusions could have been made for $H$. grandifolius depending on the selected $P-I$ model. Further, values were sometimes very dissimilar according to the chosen model. There were considerable differences produced by the equations in the estimates of $\alpha$ and $I_{\mathrm{k}}$, and also for CB although there were not so obvious.

Estimates for $P_{\max }$ with the exponential and hyperbolic tangent models are in good agreement (2\% difference). The same comparison for $\alpha$ shows poor agreement (average differences were of $34 \%$ between the two models), and for $I_{\mathrm{k}}$ (average differences were of $40 \%$ between the two models). In relation to $\mathrm{CB}$, average differences between models were of $8 \%$.

\section{Antarctic seaweed communities under a climate change scenario}

The glacial retreat has opened new space (hard substratum) in the inner Potter Cove and led to colonization by macroalgae (a total of 18 species of upright macroalgae and two genera of encrusting red algae, Quartino et al. 2013). Taking the view that the spatial distribution of the macroalgal community expanded to the inner side of Potter Cove, it is likely that the increase in macroalgal biomass leads to an enhanced production in this area. This raises the question of how changes in macroalgal productivity could affect the rest of the coastal ecosystem in Potter Cove? Several studies predict rapid changes in rocky-shore communities due to climate change. Clark et al. (2013) predict shifts from predominantly heterotrophic to autotrophic states of shallow polar sea beds, and Kortsch et al. (2012) observed marked community shifts with abrupt and persistent increase in macroalgal cover in two Arctic fjords due to the increased duration of ice-free periods. KrauseJensen et al. (2012) also reported substantial increases in the productivity and maximal depth distribution of seaweeds for kelps in Greenland.

In this whole context, we believe that future ice retreat will continue to favor macroalgal colonization in new coastal areas (with a reduced vertical distribution in areas close to the glacier run-off), causing higher productivity and carbon-sequestration but lower local biodiversity (due to glacial effect and rapid changes) as postulated by Worm et al. (2006) and Clark et al. (2013).

However, factors such as substrate, turbidity, sedimentation, ice disturbance, stress tolerance and molecular responses, and competition need to be analyzed in a multifactorial approach to better comprehend and predict the possible changes in the community and productivity of Antarctic seaweeds due to global warming.

Acknowledgments The work has been performed at Dallmann Laboratory, annex to Carlini (formerly Jubany) Station, within the framework of the scientific collaboration existing between Instituto Antártico Argentino/Dirección Nacional del Antártico and Alfred Wegener Institute, Helmholtz Centre for Polar and Marine Research. We thank the Instituto Antártico Argentino-Dirección Nacional del Antártico. We are especially grateful to the scientific, logistic and diving groups of Carlini Station-Dallmann Laboratory for their technical assistance during the Antarctic expeditions. In addition, we thank J. Robert Waaland and Thomas Mumford for their comments which helped to improve the manuscript. We gratefully acknowledge financial support by the Alfred Wegener Institute for Polar and Marine Research, Germany, DAAD, MINCYT-BMBF. The research was also supported by Grants from DNA-IAA (PICTA 7/2008-2011) and ANPCyT-DNA (PICTO 0116/2012-2015). The present manuscript also presents an outcome of the EU project IMCONet (FP7 IRSES, Action No. 319718).

\section{References}

Airoldi L (2003) The effects of sedimentation on rocky coast assemblages. In: Atkinson RJA, Gibson RN (eds) Oceanography and marine biology: an annual review. CRC Press, London, pp 161-236

Anthony KRN, Ridd PV, Orpin AR et al (2004) Temporal variation in light availability in coastal benthic habitats: effects of clouds, turbidity, and tides. Limnol Oceanogr 49:2201-2211. doi:10. 4319/lo.2004.49.6.2201

Arakawa H, Matsuike K (1992) Influence on insertion of zoospores, germination, survival, and maturation of gametophytes of brown algae exerted by sediments. Nippon Suis Gakk 58:619-625 
Arnold KE, Manley SL (1985) Carbon allocation in Macrocystis pyrifera (Phaeophyta): intrinsic variability in photosynthesis and respiration. J Phycol 21:154-167. doi:10.1111/j.0022-3646. 1985.00154.x

Bannister TT (1979) Quantitative description of steady state, nutrientsaturated algal growth, including adaptation. Limnol Oceanogr 24:76-96

Barnes D, Peck L (2008) Vulnerability of Antarctic shelf biodiversity to predicted regional warming. Clim Res 37:149-163. doi:10. 3354/cr00760

Becker S, Graeve M, Bischof K (2010) Photosynthesis and lipid composition of the Antarctic endemic rhodophyte Palmaria decipiens: effects of changing light and temperature levels. Polar Biol 33:945-955. doi:10.1007/s00300-010-0772-5

Bischof K, Hanelt D, Wiencke C (1998) UV-radiation can affect depth-zonation of Antarctic macroalgae. Mar Biol 131:597-605

Campana GL, Zacher K, Fricke A et al (2009) Drivers of colonization and succession in polar benthic macro- and microalgal communities. Bot Mar 52:655-667. doi:10.1515/BOT.2009.076

Chapman AS, Fletcher RL (2002) Differential effects of sediments on survival and growth of Fucus serratus embryos (Fucales, Phaeophyceae). J Phycol 38:894-903. doi:10.1046/j.1529-8817. 2002.t01-1-02025.x

Clark GF, Stark JS, Johnston EL et al (2013) Light-driven tipping points in polar ecosystems. Global Change Biol 12:3749-3761. doi: $10.1111 / \mathrm{gcb} .12337$

Cullen JJ (1990) On models of growth and photosynthesis in phytoplankton. Deep Sea Res 37:667-683. doi:10.1016/01980149(90)90097-F

Dennison WC, Alberte RS (1985) Role of daily light period in the depth distribution of Zostera marina (eelgrass). Mar Ecol Prog Ser 25:51-61

Di Rienzo JA, Casanoves F, Balzarini MG et al (2008) InfoStat versión 2008. Grupo InfoStat, Facultad de Ciencias Agropecuarias, Universidad Nacional de Córdoba, Córdoba

Drew EA (1977) The physiology of photosynthesis and respiration in some Antarctic marine algae. Br Antarct Surv Bull 46:59-76

Drew EA (1983) Physiology of Laminaria I. Use of excised lamina discs in short and long term experiments. PSZN I Mar Ecol 4:211-226

Drew EA, Hastings RM (1992) A year-round ecophysiological study of Himantothallus grandifolius (Desmarestiales, Phaeophyta) at Signy Island, Antarctica. Phycol 31:262-277. doi:10.2216/ i0031-8884-31-3-4-262.1

Ducklow HW, Fraser WR, Meredith MP et al (2013) West Antarctic Peninsula: an ice-dependent coastal marine ecosystem in transition. Oceanography 26(3):190-203. doi:10.5670/oceanog. 2013.62

Eggert A, Wiencke C (2000) Adaptation and acclimation of growth and photosynthesis of five Antarctic red algae to low temperatures. Polar Biol 23:609-618. doi:10.1007/s003000000130

Eraso A, Domínguez MA (2007) Physicochemical characteristics of the subglacier discharge in Potter Cove, King George Island, Antarctica. In: Tyk A, Stefaniak K (eds) Karst and cryokarst, studies of the faculty of earth sciences. University of Silesia 45:111-122

Eriksson BK, Johansson G (2005) Effects of sedimentation on macroalgae species-specific responses are related to reproductive traits. Oecologia 143:438-448. doi:10.1007/s00442-004-1810-1

Frenette J, Demers S, Legendre L, Dodson J (1993) Lack of agreement among models for estimating photosynthetic parameters. Limnol Oceanogr 38(3):679-687. doi:10.4319/lo.1993. 38.3.0679

Gómez I, Weykam G, Klöser H et al (1997) Photosynthetic light requirements, metabolic carbon balance and zonation of sublittoral macroalgae from King George Island (Antarctica). Mar Ecol Prog Ser 148:281-293. doi:10.3354/meps148281

Gómez I, Wulff A, Roleda MY et al (2009) Light and temperature demands of marine benthic microalgae and seaweeds in polar regions. Bot Mar 52: 593-608. doi: 10.1515/BOT.2009.073

Graham MH (1996) Effect of high irradiance on recruitment of the giant kelp Macrocystis (Phaeophyta) in shallow water. J Phycol 32:903-906. doi:10.1111/j.0022-3646.1996.00903.x

Hanelt D, Melchersmann B, Wiencke C, Nultsch W (1997) Effects of high light stress on photosynthesis of polar macroalgae in relation to depth distribution. Mar Ecol Prog Ser 149:255-266

Henley WJ (1993) Measurements and interpretation of photosynthetic light-response curves in algae in the context of photoinhibition and diel changes. J Phycol 29:729-739. doi:10.1111/j.00223646.1993.00729.x

Jassby AD, Platt T (1976) Mathematical formulation of the relationship photosynthesis and light for phytoplankton. Limnol Oceanogr 21:540-547. doi:10.4319/lo.1976.21.4.0540

Jones CT, Craig SE, Barnett AB et al (2014) Curvature in models of the photosynthesis-irradiance response. J Phycol. doi:10.1111/ jpy. 12164

Karsten U, Wiencke C, Kirst GO (1991a) The effect of salinity changes upon physiology of eulittoral green macroalgae from Antarctica and Southern Chile. I. Cell viability, growth, photosynthesis and dark respiration. J Plant Physiol 138:667-673

Karsten U, Wiencke C, Kirst GO (1991b) The effect of salinity changes upon physiology of eulittoral green macroalgae from Antarctica and Southern Chile II. Inorganic ions and organic compounds. J Exp Bot 42:1533-1539

Kirk JTO (1994) Light and photosynthesis in aquatic ecosystems. Cambridge University Press, Cambridge. doi:10.1017/ CBO9780511623370

Kirst GO, Wiencke C (1995) Ecophysiology of Polar algae. J Phycol 31:181-199. doi:10.1111/j.0022-3646.1995.00181.x

Klöser H, Quartino ML, Wiencke C (1996) Distribution of macroalgae and macroalgal communities in gradients of physical conditions in Potter Cove, King George Island, Antarctica. Hydrobiol 333:1-17. doi:10.1007/BF00020959

Kortsch S, Primicerio R, Beuchel F et al (2012) Climate-driven regime shifts in Arctic marine benthos. Proc Natl Acad Sci USA 109:14052-14057. doi:10.1073/pnas.1207509109

Krause-Jensen D, Marba N, Olesen B et al (2012) Seasonal sea ice cover as principal driver of spatial and temporal variation in depth extension and annual production of kelp in Greenland. Global Change Biol. doi:10.1111/j.1365-2486.2012.02765.x

Kühl M, Glud R, Borum J et al (2001) Photosynthetic performance of surface-associated algae below sea ice as measured with a pulseamplitude-modulated (PAM) fluorometer and $\mathrm{O} 2$ microsensors. Mar Ecol Prog Ser 223:1-14. doi:10.3354/meps223001

Long MH, Rheuban JE, Berg P, Zieman JC (2012) A comparison and correction of light intensity loggers to photosynthetically active radiation sensors. Limnol Oceanogr Methods 10:416-424. doi:10.4319/lom.2012.10.416

Lüning K (1990) Seaweeds-their environment, biogeography and ecophysiology. Wiley, NewYork, p 527

Markager S, Sand-Jensen K (1992) Light requirements and depth zonation of marine macroalgae. Mar Ecol Prog Ser 88:83-92. doi: $10.3354 /$ meps 088083

Matta JL, Chapman DJ (1991) Photosynthetic responses and daily carbon balance of Colpomenia peregrina: seasonal variations and differences between Intertidal and subtidal populations. Mar Biol 108:303-313. doi:10.1007/BF01344345

Miller KA, Pearse JS (1991) Ecological studies of seaweeds in McMurdo Sound, Antarctica. Am Zool 31:35-48. doi:10.1093/ icb/31.1.35 
Monien P, Schnetger B, Brumsack HJ et al (2011) A geochemical record of late Holocene palaeoenvironmental changes at King George Island (maritime Antarctica). Antarct Sci 23:255-267. doi:10.1017/S095410201100006X

Muscatine L (1980) Productivity of zooxanthellae. In: Falkowski PG (ed) Primary productivity in the sea. Plenum Press, New York, pp 403-410. doi:10.1007/978-1-4899-0762-2_14

Nelson S, Siegrist AW (1987) Comparison of mathematical expressions describing light-saturation curves for photosynthesis by tropical marine macroalgae. Bull Mar Sci 41:617-622

Pritchard DW, Hurd CL, Beardall J et al (2013) Survival in low light: photosynthesis and growth of a red alga in relation to measured in situ irradiance. J Phycol 49:867-879. doi: 10.1111/jpy.12093

Quartino ML, Boraso de Zaixso AL (2008) Summer macroalgal biomass in Potter Cove, South Shetland Islands, Antarctica: its production and flux to the ecosystem. Polar Biol 31:281-294

Quartino ML, Deregibus D, Campana GL et al (2013) Evidence of macroalgal colonization on newly ice-free areas following glacial retreat in Potter Cove (South Shetland Islands), Antarctica. PLoS One 8:e58223. doi:10.1371/journal.pone.0058223

Rückamp M, Braun M, Suckro S, Blindow N (2011) Observed glacial changes on the King George Island ice cap, Antarctica, in the last decade. Global Planet Change 79:99-109. doi:10.1016/j.glopla cha.2011.06.009

Runcie JW, Riddle MJ (2006) Photosynthesis of marine macroalgae in ice-covered and ice-free environments in East Antarctica. Eur J Phycol 41:223-233. doi:10.1080/09670260600645824

Saba VS, Friedrichs MAM, Carr ME et al (2010) Challenges of modeling depth-integrated marine primary productivity over multiple decades: a case study at BATS and HOT. Global Biogeochem Cycle 24:GB3020. doi:10.1029/2009GB003655

Schloss IR, Abele D, Moreau S et al (2012) Response of phytoplankton dynamics to 19 year (1991-2009) climate trends in Potter Cove (Antarctica). J Mar Syst 92:53-66. doi:10.1016/j. jmarsys.2011.10.006

Schloss IR, Wasilowska A, Dumont D et al (2014) On the phytoplankton bloom in coastal waters of southern King George Island (Antarctica) in January 2010: An exceptional feature? Limnol Oceanogr 59:195-210. doi:10.1594/PANGAEA.754676

Schofield O, Ducklow HW, Martinson DG et al (2010) How do polar marine ecosystems respond to rapid climate change? Science 328:1520-1523. doi:10.1126/science. 1185779

Schwarz AM, Hawes I, Andrew N et al (2003) Macroalgal photosynthesis near the southern global limit for growth; Cape Evans, Ross Sea, Antarctica. Polar Biol 26:789-799. doi:10. 1007/s00300-003-0556-2

Smith EL (1936) Photosynthesis in relation to light and carbon dioxide. Proc Nat Acad Sci 22:504-511
Southwood TRE, Henderson PA (2000) Ecological methods, 3rd edn. Blackwell, Oxford

Spurkland T, Iken K (2011) Salinity and irradiance effects on growth and maximum photosynthetic quantum yield in subarctic Saccharina latissima (Laminariales, Laminariaceae). Bot Mar 54:355-365. doi:10.1515/BOT.2011.042

Steele J (1962) Environmental control of photosynthesis in the sea. Limnol Oceanogr 7:137-150. doi:10.4319/lo.1962.7.2.0137

Torre L, Servetto N, Eöry ML et al (2012) Respiratory responses of three Antarctic ascidians and a sea pen to increased sediment concentrations. Polar Biol 35:1743-1748. doi:10.1007/s00300012-1208-1

Turner J, Colwell SR, Marshall GJ et al (2005) Antarctic climate change during the last 50 years. Int J Climatol 25:279-294. doi: $10.1002 /$ joc. 1130

Turner J, Bindschadler RA, Convey P et al (2009) Antarctic climate change and the environment. SCAR, Cambridge, pp 526

Webb WL, Newton M, Starr D (1974) Carbon dioxide exchange of Alnusrubra: a mathematical model. Oecologia 17:281-291. doi:10.1007/BF00345747

Weykam G, Gómez I, Wiencke C et al (1996) Photosynthetic characteristics and C: $\mathrm{N}$ ratios of macroalgae from King George Island (Antarctica). J Exp Mar Biol Ecol 204:1-22. doi:10.1016/ 0022-0981(96)02576-2

Wiencke C (1990a) Seasonality of brown macroalgae from Antarctica-a long-term culture study under fluctuating Antarctic daylengths. Polar Biol 10:589-600. doi:10.1007/BF00239370

Wiencke C (1990b) Seasonality of red and green macroalgae from Antarctica-a long-term culture study under fluctuating Antarctic daylengths. Polar Biol 10:601-607. doi:10.1007/BF00239371

Wiencke C, Amsler CD (2012) Seaweeds and their communities in polar regions. In: Wiencke C, Bischof K (eds) Seaweed biology, novel insights into ecophysiology, ecology and utilization Ecological Studies 219. Springer, Heidelberg, pp 265-292. doi:10.1007/978-3-642-28451-9

Wiencke C, Gómez I, Dunton K (2011) Phenology and seasonal physiological performance of polar seaweeds. In: Wiencke $\mathrm{C}$ (ed) Biology of Polar Benthic Algae. De Gruyter, Berlin, pp 181-194. doi:10.1007/978-1-4020-6285-8_13

Worm B, Barbier EB, Beaumont $\mathrm{N}$ et al (2006) Impacts of biodiversity loss on ocean ecosystem services. Science 314:787-790. doi:10.1126/science.1132294

Zacher K, Rautenberger R, Hanelt D et al (2009) The abiotic environment of polar marine benthic algae. Bot Mar 52:483-490. doi:10.1515/BOT.2009.082

Zar JH (1996) Biostatistical analysis, 3rd edn. Prentice Hall, New Jersey 